\title{
PUBLIC ADMINISTRATION IN THE FIELD OF JUSTICE IN THE CONTEXT OF EUROPEAN INTEGRATION OF UKRAINE
}

\author{
Orest Krasivskyy ${ }^{1}$, Orisia Merza ${ }^{2}$ \\ ${ }^{I}$ Doctor of History, Professor, Head of the Department of European Integration and Law of Lviv Regional \\ Institute for Public Administration of the National Academy for Public Administration (LRIPA NAPA), Lviv, \\ Ukraine, e-mail: krasivski@ukr.net, ORCID: https://orcid.org/0000-0002-7028-6038 \\ ${ }^{2}$ Postgraduate student of the department Euro integration, Lviv Regional Institute for Public Administration \\ of the National Academy for Public Administration under the President of Ukraine, e-mail: \\ orysjam@gmail.com, ORCID: https://orcid.org/0000-0002-5425-4802
}

\begin{abstract}
It is determined that administration in the field of justice should be understood as activities aimed at fulfillment of tasks of organizational nature for exercise of rights and interests of legal entities, individuals and the state, as well as the task of strengthening the law and order in the country. Emphasis is placed on the fact that one of the peculiarities of justice is the plurality of objects in this area of administration. Such objects of justice as judicial institutions, notary offices, civil registration bodies, forensic institutions and the bar are presented for consideration. It was also notes, that they all have different legal status, differ in their purpose and nature of competence. It was noted that the main purpose of administration in the field of justice is to ensure the legality, organization of protection of rights and legitimate interests of individuals and legal entities, as well as the state. Administrative and legal regulation in the field of justice is carried out on the basis of the following statutory instruments: the Laws of Ukraine "On Notaries", dated September 02, 1993, "On the Bar and Advocacy", dated December 19, 1992, "On State Registration of Civil Status Acts", dated July 01, 2010, "On Bodies and Persons Who Perform the Enforcement of Court Decisions and Decisions of Other Authorities", dated June 02, 2016, Regulation on the State Migration Service of Ukraine, dated September 20, 2014, etc. It is noted that, along with the Ministry of Justice, State Archive Service of Ukraine, State Executive Service of Ukraine, State Penitentiary Service of Ukraine, State Registration Service of Ukraine, State Service of Ukraine for the Protection of Personal Data also belong to the system of entities in the field of justice of Ukraine. It is noted that the Constitution stipulates that the judicial bodies of Ukraine have a prominent place among the law enforcement agencies of the state.
\end{abstract}

Keywords: justice, judicial bodies, public administration, organizational and legal principles

JEL Classification: H70, K33, M10

Formulas: 0; fig.: 0; tabl.: 0; bibl.: 8

Introduction. Legal supports of the processes that can be observed in the political and socio-economic spheres of Ukraine over the last decade have become increasingly relevant and urgent. Since strict and mandatory observance of the norms adopted in a civilized society is the key to the confident development of the state, consolidation of efforts to strengthen the law and order is a priority for all government institutions. Implementation of the state's administrative and regulatory functions in the field of justice is the vector that determines the direction of action aimed at development of the Ukrainian statehood.

Formation and implementation of legal state policy depends directly on the efficiency of functioning of the judicial bodies, which are called to carry out statepower activities. During the establishment of the Ukrainian state, judicial authorities changed their status, as well as the ways and forms of exercising their powers. As experience shows, there is a lack of a comprehensive understanding of the nature and place of judicial bodies in the system of executive authorities, which is a consequence 
of their inconsistent institutionalization and fragmented regulation of their status. This feature is a significant obstacle for the implementation by the Ukrainian state of European integration aspirations both in short and long terms.

Legal support for the processes that have been observed in the political and socio-economic fields of Ukraine over the last decade have become increasingly relevant and urgent. The scrupulous and compulsory observance and implementation of the norms adopted in a civilized society is the key to the stable development of the state, therefore the consolidation of efforts to strengthen the rule of law and order is a paramount task of all the state and governmental institutions. Implementation by the state of administrative functions in the field of justice is the vector that determines the course and direction of actions for the development of Ukrainian statehood.

Literature review. Such researchers as I.A. Artemenko, N.A. Zhelezniak, Y.V. Melnyk, I.I. Mykulets, L.R. Nalyvaiko, I.Y.Onopchuk, S.E. Thurin et al. in their scientific works raised the questions dedicated to the main principles of public administration in the field of justice. However, their publications mainly reflect only certain aspects of the concept of justice, legal status of justice bodies and peculiarities of public administration in the mentioned area, while complex approach to understanding of the problems of organizational and legal principles of public administration in the field of justice of Ukraine is not disclosed.

Aims. The purpose of this article is to evaluate theoretical approaches to understanding the essence of organizational and legal foundations of public administration in the field of justice of Ukraine, to analyze the activities and powers of the main authorities in the field of justice and to present proposals for development of Ukrainian justice in general.

Methods. The author used the historical method, method of scientific abstraction, method of analysis and synthesis, which made the achievement of the goal possible.

Results. Significant social, economic and political changes that have taken place in Ukraine over the past 10-15 years have clearly demonstrated the importance of legal counseling and support for the processes implemented. The law itself is capable of consolidating efforts and ensuring the obligatory observance of certain rules. It should be said that the law is an objective category, while on behalf of both the state and from non-state institutions the bodies, organizations or individuals act, who implement (enforce) the lawfulness, human rights advocacy, confirmation of rights and legally significant facts. All these things are combined in the concept of justice.

An important role in this area is played by the administration in the field of justice, which envisages activities aimed at fulfilling the tasks of strengthening the legitimacy, organization of protection of rights and legitimate interests of citizens and their associations, enterprises, institutions, organizations and the state [1].

One of the peculiarities of justice is the plurality of objects in this area of administration. The objects of justice include judicial institutions, notary offices, civil registration bodies, forensic institutions and the Bar. They all have different legal status, differ in their purpose and nature of competence. 
Another feature of justice is derives from the previous one, and it lies in the variety of forms and methods of administration used by the judicial authorities. Thus, the method of administration is applied to state notary offices and civil registration bodies; and the method of regulation is applied to the bar. In general, administrative influence of the bodies, which administer the justice, is advisory in nature and comes down to organizational issues, since most objects in this field are independent in their practical activity.

The main purpose of administration in the field of justice is to ensure the legality, organization of protection of rights and legitimate interests of individuals and legal entities, as well as the state. The objects of state influence in the field of justice include the system of judicial institutions, state and private notaries, bar, civil registration bodies, forensic institutions, executive service bodies, system of legal education of the population, etc. Administrative and legal regulation in the field of justice is carried out on the basis of the following statutory instruments: the Laws of Ukraine dated September 02, 1993 "On Notaries", dated December 19, 1992 "On the Bar", dated July 01, 2010 "On State Registration of Civil Status Acts", dated March 24, 1998 "On State Enforcement Service", etc.

The system of administrating entities in the field of justice of Ukraine includes: - Ministry of Justice of Ukraine;

- State Archival Service of Ukraine;

- State Enforcement Service of Ukraine;

- State Penitentiary Service of Ukraine;

- State Registration Service of Ukraine;

- State Service of Ukraine for Protection of Personal Data.

In the independent Ukrainian state, the Constitution [2] stipulates that the judicial bodies have a prominent place among the law enforcement agencies of the state. However, in spite of their weight and importance for the society, judicial bodies are still in the process of reformation, which is in line with the overall administrative reform. They are a wide-ranging system of governing bodies that are designed to implement the legal policy of the state. Each of these bodies has specific features and tasks; each of them occupies a clearly defined place in a complex hierarchy and has a corresponding legal status.

Thus, in practice, there is a distinction between two categories: judicial bodies and bodies of the Ministry of Justice of Ukraine [3]. The second category is part of the first one, as it is much wider in structure and in the range of authorities of its bodies. In particular, the second category is headed by the Ministry of Justice of Ukraine, which is positioned as the central authority of the state executive power, administration of which is directed and coordinated by the Cabinet of Ministers of Ukraine.

The State Archival Service of Ukraine is a part of the system of executive bodies and ensures implementation of the state policy in the field of archival affairs, record keeping, creation and functioning of the state system of the insurance fund of documentation, as well as cross-sectoral coordination on matters within its competence. 
The State Enforcement Service of Ukraine is a part of the system of executive bodies and ensures implementation of the state policy in the field of organization of enforcement of decisions of courts and other bodies (officials) in accordance with the laws.

The State Penitentiary Service of Ukraine is a part of the system of executive bodies and ensures implementation of the state policy in the field of execution of criminal penalties.

The State Registration Service of Ukraine is the central executive body, whose the main task is implementation of the state policy in the fields of state registration of civil status acts, state registration of material rights to real estate, state registration of entrepreneurs, associations of citizens, other public formations, charters of the funds for obligatory state social insurance.

The State Service of Ukraine for the Protection of Personal Data is the central executive body, which ensures implementation of the state policy in the field of protection of personal data.

An important area of work of the Ministry of Justice of Ukraine is the organization of activities of notarial bodies and registration of bar associations. Notarial systems of Ukraine is a system of bodies and officials entrusted with the duty to certify rights, as well as facts of legal importance, and to perform other notarial deeds provided for by the Law "On Notaries" in order to give them legal credibility. The legal basis for organization and activities of the notarial service is enshrined in the said Law, according to which notarial deeds in Ukraine are entrusted to notaries, who work in state notarial offices, state notarial archives (state notaries) or are engaged in private notarial activities. Documents issued by state notaries and by private notaries have the same legal force.

In settlements where there are no state notaries, certain notarial deeds are performed by the officials of the executive committees of village, town and city councils. Also, certain notarial deeds are carried out by the authorized officials of consular institutions of Ukraine, located abroad.

According to the Constitution of Ukraine (Article 59), everyone has the right to receive legal assistance. A special place among the institutions providing the realization of this right occupies the bar, which is destined to perform important tasks in providing professional legal assistance to citizens, businesses, institutions, organizations and public associations.

The bar is a voluntary professional public association, which, in accordance with the Constitution, is designed to promote the protection of rights and freedoms and to represent the legitimate interests of citizens of Ukraine, foreign citizens, stateless persons, legal entities, and to provide them with other legal assistance.

Pursuant to the Law "On the Bar" [4], legal assistance by the lawyers is provided through: providing consultations, clarifications, references, recommendations, legal advice; drafting of legal documents (lawsuits, complaints, etc.); representation in courts of general jurisdiction in civil, administrative and criminal cases; legal service for enterprises, institutions, organizations, individual citizens under the separate contracts. 
Formation and functioning of the judicial system is also influenced by the High Council of Justice, whose administrative powers have recently expanded, in particular after the entry into force of the Law "On Judiciary and Status of Judges". In the High Council of Justice resolving of a number of issues concerning the functioning both of judicial and prosecutorial systems are vested. Its competence include: filing submissions to the President of Ukraine on the appointment and dismissal of judges, appointing judges on the submission of the respective Council of Judges to the position of the presiding judge, deputy presiding judge and dismissing them from these positions, considering cases of violation by the judges of the requirements concerning consistency with the job, etc. Its main task is the formation of a highly professional judicial corps of highly qualified jurists, who are able to abide by the law and to administer justice honestly and impartially.

The High Council of Justice is formed by the three branches of power legislative, executive and judiciary, as well as by the prosecutorial system and the institutes of civil society: the bar, educational and scientific legal circles.

Development of the law-governed state and of civil society obliges the administering bodies in the field of justice not only to ensure the implementation of the state legal policy, but also to strengthen the influence on its formation. Priorities for the development of the Ukrainian justice today are the following:

- formation of a new, higher level of legal awareness and legal culture of citizens;

- reforming of the judicial system to ensure the accessibility of justice and the effectiveness of judicial protection;

- reforming of the criminal justice and the criminal executive system;

- creating legal frameworks for prevention and counteraction to corruption;

- ensuring the efficiency of the enforcement of court decisions;

- improvement of the system of protection of state interests in the courts of Ukraine;

- formation of a free legal aid system.

As Ukraine's strategic goal is to become a full member of the European Union, then, to fulfill its aspirations for European integration, Ukrainian state needs to fulfill a number of conditions set by the European Union, as well as to adhere to the regulations, norms and standards existing in various fields, including in the field of justice.

If we talk about public administration in the field of justice in the context of the European integration of Ukraine, then the activity of the judicial bodies must be in harmony with the European standards. As the cooperation between Ukraine and the European Union in the field of justice has a regulatory framework governing the general directions of bilateral cooperation, it can be argued that the justice bodies are generally prepared to function in the context of implementation of the European integration vector of the Ukrainian state. However, in order for these relationships to keep developing in a harmonious manner, it is necessary that legal support was sufficient in all areas of such interaction. Ukraine needs to work on deepening and 
expanding mutually beneficial relations and fulfilling its long-term aspirations for European integration.

It should be noted that the cooperation between Ukrainian and European Union is taking place within the framework of the EU-Ukraine Action Plan on Justice, Freedom and Security (Justice, Freedom and Security Action Plan, approved in June, 2007), Implementation Plan (approved in April, 2008) and other documents.

These statutory instruments define the terms of cooperation between Ukraine and the European Union in accordance with fifteen key directions. In particular, we talk about such directions as: legal cooperation in civil and criminal cases, anticorruption enforcement, drug trafficking, human trafficking, anti-money laundering, counter-terrorist financing, fight against terrorism and organized crime, document security, border management, visa matters, migration, asylum and other problems that exist in the field of justice on the international level.

The EU-Ukraine Justice, Freedom and Security Action Plan states that the main challenges and strategic goals of cooperation between the Ukrainian state and the European community are the following [5]:

- strengthening of partnership and practical cooperation between the European Union, its Member States and Ukraine in the fields of justice, freedom and security;

- supporting Ukraine's efforts in strengthening the democracy, protecting human rights and fundamental freedoms. Promoting the stability and effectiveness of the relevant public institutions for overall strengthening of the supremacy of law;

- continuing to work with Ukraine to ensure the application of principles of the supremacy of law, independence and efficiency of the judiciary power, including access to justice and proper governance;

- insuring the ratification and full implementation of the most important international instruments in the field of justice and internal affairs;

- continuing to create an appropriate legal framework for effective cooperation in the area of justice, freedom and security in accordance with international and EU standards, as well as to work to ensure the effective implementation and application of such standards;

- intensifying efforts to strengthen institutional capacities with involvement when needed of the public, including the use of the capacity of non-governmental organizations and business representatives.

Among the adopted regulatory instruments, the Association Agreement between Ukraine and the EU is of key importance [6]. The said Agreement embodies one of the important steps that the Ukrainian state is undergoing towards European integration. However, this is not enough to become a full member of the EU - in order to do so, Ukraine must, in addition to many other conditions, bring its legislation in line with the existing in Europe standards in the field of justice, freedom, security and movement of persons.

The Association Agreement was preceded by the Partnership and Cooperation Agreement between the European Communities and their Member States on the one side and Ukraine on the other side. This document provided for the possibility of signing of further agreements between the parties interested in further cooperation. 
These negotiations began in 2007 and during the subsequent five years 21 rounds of negotiations were held within the framework of signing of the EU-Ukraine Association Agreement and 18 rounds of negotiations that provided for a participation in the Agreement on Creation of a Deep and Comprehensive Free Trade Area.

Discussion. In general, signing of the Association Agreement is not an end in itself, since Ukraine does not become a full member of the EU. Any association provides for the formation of a legal framework and a favorable climate in order to create favorable conditions for a potential member of the European Union. In this case, there are no clear rules for the relationship between the parties. The agreement is aimed at leading the signatories to participation in the European community in the future.

Of course, with the adoption of the Association Agreement Ukraine's European aspirations will not cease. The Parties continue to work on deepening the mutually beneficial relations. Thus, Ukraine conducts negotiations with the EU Member States on conclusion of the implementation protocols to the said document. The relevant negotiations with the competent authorities of the EU Member States are conducted by the State Migration Service of Ukraine [7].

Adoption of a visa-free regime between Ukraine and the European Union has intensified the movement of Ukrainian citizens across European borders. Accordingly, the State Migration Service of Ukraine has also intensified its work by increasing the issue of biometric passports.

Thus, the public administration in the field of justice of Ukraine has a number of features that define its social orientation and management of various branches of the national economy of the state, determine the executive and administrative nature of its functioning and accountability, subordination and control by the higher authorities.

Therefore, taking into account the above-mentioned features of the bodies performing public administration in the field of justice of Ukraine and implementing the European integration aspirations by the Ukrainian state, we can formulate the author's approach to the interpretation of the judicial bodies in accordance with the current conditions of development of Ukrainian society on the way to integration into the European community. In our view, judicial bodies shall be understood as the bodies of executive power, which are vested with administrative state-power authorities in the field of justice and the related areas in accordance with the current legislation, have at their disposal the necessary material, organizational, financial and labor resources, carry out systematic socially-oriented activities, as well as control political, economic, administrative and social processes in the country in the direction of implementation by Ukraine of the European vector of development.

Conclusions. Strategic priorities of Ukraine for pursuing European integration aspirations have a solid basis. In the area of justice, there is an appropriate legal framework through which Ukraine is constantly moving in the European direction and ensures that the key conditions set by the European Union were fulfilled. 
Considering the European integration aspect of the policy of the Ukrainian government, it should be emphasized that the activities of the judicial bodies must be in line with European standards. Taking into account that the cooperation between Ukraine and the European Union in the field of justice has a regulatory framework governing the general directions of bilateral cooperation, it can be argued that the judicial bodies are generally prepared to function in the context of implementation of the European integration vector of the Ukrainian state. However, in order for these relationships to continue to develop in a harmonious manner, it is necessary that legal support was sufficient in all areas of such interaction. Ukraine needs to work on deepening and expanding mutually beneficial relations and fulfilling its long-term aspirations for European integration.

Author contributions. The authors contributed equally.

Disclosure statement. The authors do not have any conflict of interest.

\section{References:}

1. Association Agreement between Ukraine and the European Union, retrieved from : http://www.kmu.gov.ua/docs/Agreement/AA_Body_text.pdf.

2. The Verkhovna Rada of Ukraine (1996), The Law of Ukraine "The Constitution of Ukraine" No. 254k 196-SG, retrieved from : https://zakon.rada.gov.ua/laws/show/254\%D0\%BA/96-\%D0\%B2\%D1\%80\#Text.

3. Cabinet of Ministers of Ukraine (2014), "On approval of the Regulation on the Ministry of Justice of Ukraine", July 22m 2014 No. 228. Article 1455.

4. The Verkhovna Rada of Ukraine (2014), The Law of Ukraine "On the Bar and Advocacy", retrieved from : https://zakon.rada.gov.ua/laws/show/5076-17\#Text.

5. The official site of Studies (2020), "Organizational and Legal Principles of Public Administration in the Field of Justice", retrieved from : http://studies.in.ua/admin-pravo-shpora/2946-organzacyno-pravov-zasadiderzhavnogo-upravlnnya-u-sfer-yusticyi.html

6. Cabinet of Ministers of Ukraine (2014), "On approval of the Regulations on the State Migration Service of Ukraine", retrieved from : https://zakon.rada.gov.ua/laws/show/360-2014-\%D0\%BF\#Text.

7. The EU-Ukraine Justice, Freedom and Security Action Plan, retrieved from : http://www.kmu.gov.ua/document/226050661/PD_USB.doc.

8. Karpa, M., Akimov, O., \& Shykerynets, V. (2020). Implementation of innovative forms and models of public administration in the sphere of culture in Ukraine. Public Administration and Law Review, (3), 13-23. https://doi.org/10.36690/2674-5216-2020-3-13. 